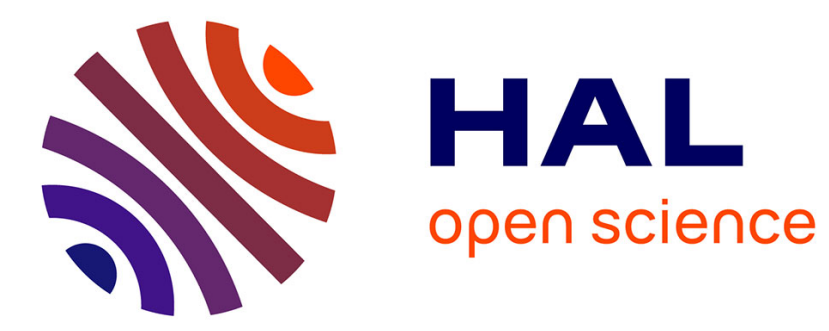

\title{
Characteristics of Nosema ceranae infection in Serbian honey bee colonies
}

Jevrosima Stevanovic, Predrag Simeunovic, Bojan Gajic, Nada Lakic, Dejan

Radovic, Ingemar Fries, Zoran Stanimirovic

\section{- To cite this version:}

Jevrosima Stevanovic, Predrag Simeunovic, Bojan Gajic, Nada Lakic, Dejan Radovic, et al.. Characteristics of Nosema ceranae infection in Serbian honey bee colonies. Apidologie, 2013, 44 (5), pp.522-536. 10.1007/s13592-013-0203-z . hal-01201323

\section{HAL Id: hal-01201323 \\ https://hal.science/hal-01201323}

Submitted on 17 Sep 2015

HAL is a multi-disciplinary open access archive for the deposit and dissemination of scientific research documents, whether they are published or not. The documents may come from teaching and research institutions in France or abroad, or from public or private research centers.
L'archive ouverte pluridisciplinaire HAL, est destinée au dépôt et à la diffusion de documents scientifiques de niveau recherche, publiés ou non, émanant des établissements d'enseignement et de recherche français ou étrangers, des laboratoires publics ou privés. 


\title{
Characteristics of Nosema ceranae infection in Serbian honey bee colonies
}

\author{
Jevrosima Stevanovic ${ }^{1}$, Predrag Simeunovic ${ }^{1}$, Bojan GaJiC $^{2}$, Nada Lakic ${ }^{3}$, \\ Dejan Radovic ${ }^{4}$, Ingemar Fries $^{5}$, Zoran Stanimirovic ${ }^{1}$ \\ ${ }^{1}$ Department of Biology, Faculty of Veterinary Medicine, University of Belgrade, Bul. oslobodjenja 18, 11000 \\ Belgrade, Serbia \\ ${ }^{2}$ Department of Parasitology, Faculty of Veterinary Medicine, University of Belgrade, Bul. oslobodjenja 18, 11000 \\ Belgrade, Serbia \\ ${ }^{3}$ Department of Statistics, Faculty of Agriculture, University of Belgrade, Nemanjina 6, 11081 Belgrade-Zemun, \\ Serbia \\ ${ }^{4}$ Institute of Zoology, Faculty of Biology, University of Belgrade, Studentski trg 16, 11000 Belgrade, Serbia \\ ${ }^{5}$ Department of Ecology, Swedish University of Agricultural Sciences, P.O. Box 7044, Ulls väg 16, 75007 Uppsala, \\ Sweden
}

Received 5 November 2012 - Revised 5 February 2013 - Accepted 27 February 2013

\begin{abstract}
The incidence, symptoms and consequences of Nosema ceranae infection were monitored in 200 honey bee colonies in Serbia over 5 years (2008-2012) to reveal if they display characteristics described for nosemosis type C. Continual high frequency of $N$. ceranae-positive colonies was recorded within each study year, ranging from 73 to $98 \%$. A seasonal pattern in $N$. ceranae incidence was observed over 4 years (20082011). Symptoms traditionally attributed to Nosema apis infection were observed in the majority of $N$. ceranaeinfected colonies, both among surviving and those that died. These symptoms could not serve as predictive markers for colony losses, as they were significantly more frequently observed among surviving colonies in 2010, 2011 and 2012. No clear association between N. ceranae infection and colony losses was affirmed neither during the winter nor during the summer season. Thus, $N$. ceranae infection in Serbian bees do not fit the characteristics for nosemosis type C.
\end{abstract}

\section{Nosema ceranae / Apis mellifera / nosemosis type C / faeces}

\section{INTRODUCTION}

Two microsporidian species, Nosema apis (Zander 1909) and Nosema ceranae (Fries et al. 1996), may infect adult honey bees. Although it was considered for a long time that $N$. apis was a pathogen specific for the European honey bee, Apis mellifera, and $N$. ceranae for the Asian

Jevrosima Stevanovic and Predrag Simeunovic contributed equally to this work.

Corresponding author: J. Stevanovic, rocky@vet.bg.ac.rs

Manuscript editor: David Tarpy honey bee, Apis cerana, many recent reports have revealed that the latter infect $A$. mellifera worldwide (Higes et al. 2006; Fries et al. 2006; Huang et al. 2007; Klee et al. 2007; Paxton et al. 2007; Chauzat et al. 2007; Chen et al. 2008; Williams et al. 2008; Invernizzi et al. 2009; Tapaszti et al. 2009; Giersch et al. 2009; Stevanovic et al. 2011; Nabian et al. 2011; Dainat et al. 2012). Previously, $N$. ceranae was considered an emergent pathogen suspected to replace $N$. apis in $A$. mellifera (Klee et al. 2007). However, there are evidence that $N$. ceranae has been present in the western honey bees for longer than 20 years (Paxton et al. 2007; Chen et al. 2008; Invernizzi et al. 2009) without actually 
replacing N. apis (Fernández et al. 2012) and with a less pronounced prevalence in northern climates (Fries and Forsgren 2008; Gisder et al. 2010).

In Serbia and neighbouring countries (Hungary, Croatia, Bosnia and Herzegovina, Montenegro, Former Yugoslav Republic of Macedonia and Greece) N. ceranae totally dominates in Microsporidia infections in honey bees (Tapaszti et al. 2009; Tlak Gajger et al. 2010; Bacandritsos et al. 2010; Stevanovic et al. 2011). Detection of only N. ceranae in historical samples of Serbian bees (collected between 2000 and 2005) indicated that this species has been present in Serbia since at least the year 2000 (Stevanovic et al. 2011). Today, it is not possible to determine the species of earlier findings of Microsporidia infections in honey bees from this region. Thus, it is not possible to determine if $N$. ceranae has become more prevalent at the expense of $N$. apis or if both parasites may vary in prevalence independently. The idea of replacement of $N$. apis by $N$. ceranae is not supported by studies of the ' $N$. apis/ $N$. ceranae/honey bee' relationship in laboratory assays. Neither $N$. apis nor $N$. ceranae has been shown to exert any clear competitive advantage in co-infections (Forsgren and Fries 2010) and neither of these parasites excludes the other, either at the colony level or at the individual level (Martín-Hernández et al. 2011a).

Differences in epidemiological pattern, symptomology and pathology were observed between the disease caused by $N$. ceranae and $N$. apis (Higes et al. 2010a). Thus, two different clinical patterns of nosemosis were proposed: nosemosis type A caused by N. apis and type C by N. ceranae. This nomenclature was agreed by the COLOSS workshop (2009), reviewed in Higes et al. (2010a).

Nosemosis type A was characterised, in its acute form, by dysentery (brown faecal marks on combs, frames and the front of the hives), sick and dead bees in the vicinity of the hives, a decrease in brood production and in the size of the honey bee colony particularly in spring. Also, N. apis exhibits a clear seasonality in infection prevalence and colony collapse occur mainly in early spring, i.e. before the foraging season starts (Bailey 1955, 1967). However, such clinical features were not reported for nosemosis type C, at least in Spain where a lack of seasonality have been reported with the absence of any clear symptoms and eventually collapse of infected colonies if treatment was not administered (Martín-Hernández et al. 2007; Higes et al. 2008, 2009, 2010a). However, in Germany, the absence of seasonality in $N$. ceranae prevalence could not be confirmed (Gisder et al. 2010).

Reports on the impact of $N$. ceranae infection on honey bee health and colony survival are contradictory, so its role in colony losses is not fully understood (Paxton 2010). In Spain, significant causative association between $N$. ceranae and colony losses have been reported (MartínHernández et al. 2007; Higes et al. 2008; 2009), and this pathogen has been considered to be a key factor in colony losses detected over the last decade in that Mediterranean country (Higes et al. 2010b). However, also from Spain existing data appear contradictory. Both $N$. ceranae and N. apis have been reported to be present in beehives without causing disease symptoms or colony collapse (Fernández et al. 2012).

Several investigations from different geographical regions found that $N$. ceranae may be involved in colony losses, but in the combination with other synergistic factors (Alaux et al. 2010; Bromenshenk et al. 2010; Bacandritsos et al. 2010; Vidau et al. 2011), whilst many investigations could not confirm that $N$. ceranae infection alone inevitably leads to colony loss (Cox-Foster et al. 2007; vanEngelsdorp et al. 2009; Genersch et al. 2010; Gisder et al. 2010; Vejsnæs et al. 2010; Stevanovic et al. 2011; Dainat et al. 2012). Such discrepancies in data at the colony-level pathology, characteristics and outcome of $N$. ceranae infections in different parts of the world may be due to the influence of climatic factors (Fries 2010; Higes et al. 2010a; Paxton 2010; Gisder et al. 2010). Insufficient data on epidemiological factors, clinical symptoms of $N$. ceranae disease and the impacts of $N$. ceranae on A. mellifera in different areas in Europe and rest of the world, suggest a great need for such investigation in different geographical areas, defined beekeeping management and climatic conditions (Higes et al. 2010a; Fries 2010). 
In this study, we monitored the incidence, symptoms and consequences of $N$. ceranae infection in 200 honey bee colonies in Serbia over 5 years (2008-2012). The objective was to investigate if $N$. ceranae infections in Serbian honey bee colonies is characterised by lack of seasonality, the absence of clinical symptoms and is associated with colony loss, as previously described for nosemosis type C caused by $N$. ceranae in Spain (COLOSS workshop 2009; reviewed in Higes et al. 2010a). In addition, the adequacy of faeces and dead bees for Nosema diagnostic purposes was also assessed.

\section{MATERIALS AND METHODS}

\subsection{Honey bee colonies}

A total of 200 colonies from 20 distant apiaries in Serbia (ten randomly selected colonies per apiary), including the apiary at the Faculty of Veterinary Medicine in Belgrade, were monitored for Nosema infection between spring 2008 and summer 2012. Selected apiaries were situated at locations distributed throughout Serbia in both flatland and mountainous parts, thus under different climatic conditions (see Figure 1). At each visit to the apiary, all colonies were checked for both bee and brood pathology by a veterinary specialist for bee diseases (co-author of this article) following methods described in the Manual of Diagnostic Tests and Vaccines for Terrestrial Animals published by the Office International des Epizooties (OIE 2008) to confirm the absence of any bee disease other than Nosema infection. Varroa destructor infestation was controlled during the study by two yearly treatments, with amitraz $\left(\right.$ Varamit $\left.^{\circledR}\right)$ or with fluvalinat $\left(\right.$ Varotom $\left.{ }^{\circledR}\right)$, alternating the products each year. No fumagillin or alternative treatment against Nosema were undertaken in any of 200 selected colonies. In surrounding areas, there were sufficient quantities of pollen during the foraging season, and no genetically modified agricultural crops were cultivated. All colonies were supplied with $2 \mathrm{~L}$ of sugar syrup (sugar/water, 1:1) in the autumn and sugar patty at the end of the January. No changes were made in beekeeping practices during the study. To maintain the same number of monitored hives, each colony that died was replaced. The numbers of colonies that died are presented in Tables IV, V and VI.
Overall, 237 colonies were replaced $(48+58+70+51-$ died during the winter season of the respective year and $4+5+8+3$ - died during the summer season of the respective year).

\subsection{Samples}

Adult live bees were sampled three times a year (in March, June and October). As first sampling was done in March 2008, and last in June 2012 (Figure 2), a total of 2,800 bee samples were taken on 14 sampling occasions. Each sample consisted of 100 live adult bees. In March, live bees were collected either from the cluster (Gisder et al. 2010) or from the hive entrance after closing it for 2030 min (Meana et al. 2010; Botías et al. 2012), depending on climate and availability of foragers. In June and October, around 100 foragers from the hive entrances were collected from each colony. All collected samples were frozen at $-20{ }^{\circ} \mathrm{C}$ and stored until analysis. In addition, samples of faeces and dead bees were collected in March in order to reveal if such samples are adequate for Nosema detection and species identification. Faeces were sampled each year when found on hive structures. A total of 1,788 faecal samples were collected, analysed by microscopy and PCR, and the results compared with those obtained from analysis of live bees sampled on the same day from the same colony. Dead bees from bottom boards were sampled only in the first year of the investigation (March 2008) because 24 of 200 colonies infected with $N$. ceranae (affirmed by analyses of faeces) appeared Nosema negative when collected dead bees were analysed (both microscopically and by PCR). Thus, dead bees were excluded as non-adequate for Nosema detection, and only live bees and faeces were sampled in the following years.

\subsection{Detection of Nosema infection and determination of Nosema species}

A simple, non-quantitative method recommended by OIE (2008) was used for detecting Nosema infection from live bee samples. Briefly, at least 60 bee abdomens from each sample were macerated in $2-3 \mathrm{~mL}$ of water and suspension was examined microscopically at $\times 400$ magnification. Suspensions of all samples, including those that appeared Nosema negative by microscopic analysis, were stored at $-20{ }^{\circ} \mathrm{C}$ and subsequently subjected to PCR analysis to check the reliability of 


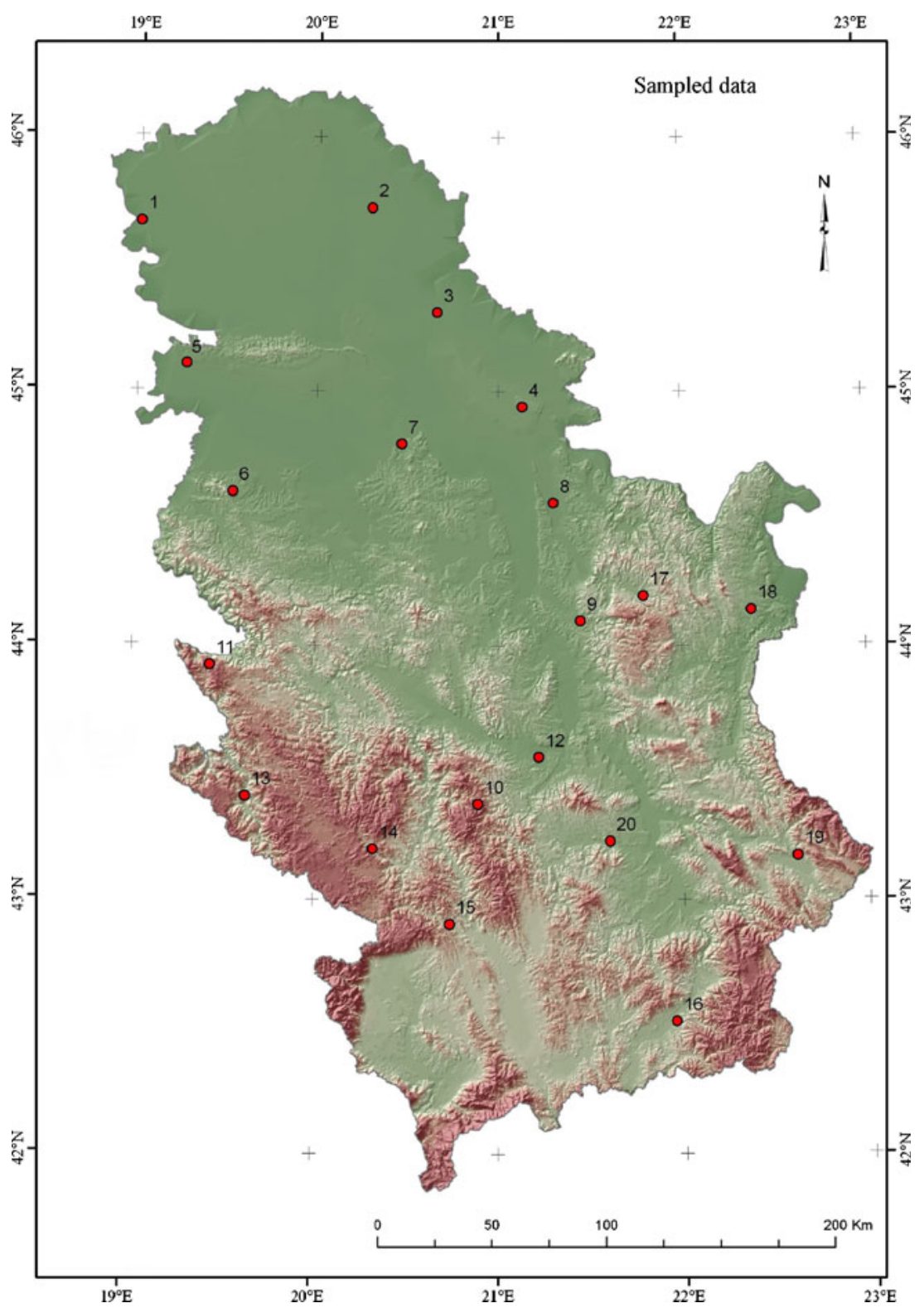

Figure 1. Geographical distribution of monitored apiaries (1, Apatin; 2, Novo Milosevo; 3, Botos; 4, Susara; 5 , Gibarac; 6, Cer; 7, Beograd; 8, Kaliste; 9, Despotovac; 10, Kriva Reka; 11, Dobro Polje; 12, Mackovac; 13, Zalug; 14, Rogatac; 15, Ugljare; 16, Cmilovac; 17, Zagubica; 18, Metris; 19, Pirot; and 20, Prokuplje).

the microscopic method for Nosema detection from live bees. For DNA extraction, $1 \mathrm{~mL}$ of spore suspension was washed twice with $\mathrm{ddH}_{2} \mathrm{O}$ by centrifugation $(5 \mathrm{~min}$, $16,100 \times g)$. Pellets were frozen in liquid nitrogen, crushed using sterile pellet pestles and used for DNA extraction by DNeasy Plant Mini Extraction Kit
(Qiagen, cat. No. 69104). The extracts were kept at $-20{ }^{\circ} \mathrm{C}$ until needed as DNA template in PCRs.

Faecal samples were also checked for Nosema spores under the light microscopy. Approximately $200 \mathrm{mg}$ of faeces was homogenised in $1 \mathrm{~mL}$ of $\mathrm{ddH}_{2} \mathrm{O}$ to obtain the suspension clear enough to 


\begin{tabular}{|c|c|c|c|c|c|c|c|c|c|c|c|c|c|c|c|}
\hline \multirow{2}{*}{ Colonies } & \multirow{2}{*}{$\begin{array}{l}\text { N. ceranae } \\
\text { incidence }\end{array}$} & \multicolumn{3}{|c|}{2008} & \multicolumn{3}{|c|}{2009} & \multicolumn{3}{|c|}{2010} & \multicolumn{3}{|c|}{2011} & \multicolumn{2}{|c|}{2012} \\
\hline & & March & June & October & March & June & October & March & June & October & March & June & October & March & June \\
\hline N. ceranae- & Number & 188 & 156 & 166 & 190 & 152 & 158 & 196 & 146 & 152 & 192 & 170 & 174 & 192 & 182 \\
\hline positive & $\%$ & 94 & 78 & 83 & 95 & 76 & 79 & 98 & 73 & 76 & 96 & 85 & 87 & 96 & 91 \\
\hline N. ceranae- & Number & 12 & 44 & 34 & 10 & 48 & 42 & 4 & 54 & 48 & 8 & 30 & 26 & 8 & 18 \\
\hline negative & $\%$ & 6 & 22 & 17 & 5 & 24 & 21 & 2 & 27 & 24 & 4 & 15 & 13 & 4 & 9 \\
\hline \multirow{2}{*}{ Total } & Number & 200 & 200 & 200 & 200 & 200 & 200 & 200 & 200 & 200 & 200 & 200 & 200 & 200 & 200 \\
\hline & $\%$ & 100 & 100 & 100 & 100 & 100 & 100 & 100 & 100 & 100 & 100 & 100 & 100 & 100 & 100 \\
\hline
\end{tabular}

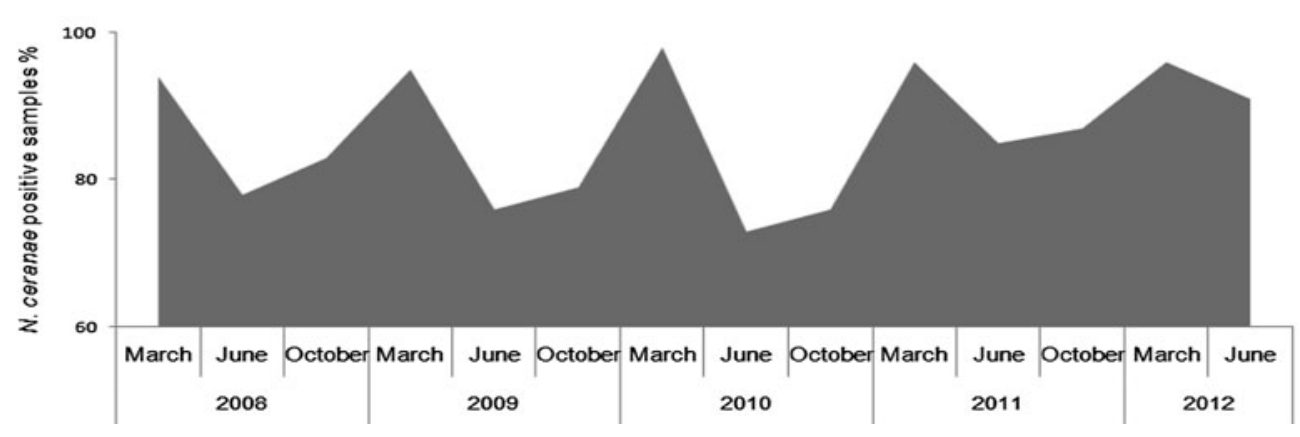

Figure 2. The incidence of $N$. ceranae infected honey bee colonies in Serbia at three sampling months during the period March 2008-June 2012 (based on PCR analyses of live bee samples).

observe spores microscopically at $\times 400$ magnification. For PCR identification of Nosema species, DNA was extracted from the pellet obtained after centrifugation of faecal suspension for $5 \mathrm{~min}$ at $16,100 \times \mathrm{g}$. The pellet was frozen in liquid nitrogen, crushed using sterile pellet pestles and re-suspended in $1 \mathrm{~mL}$ of $\mathrm{ddH}_{2} \mathrm{O}$, vortexed for $1 \mathrm{~min}$ and $0.5 \mathrm{~mL}$ of the mixture discarded. The rest of the suspension was subjected to two rounds of dilution as follows: tubes were refilled to $1 \mathrm{~mL}$ with $\mathrm{ddH}_{2} \mathrm{O}$, vortexed and $0.5 \mathrm{~mL}$ of the mixture discarded. After the second dilution step, $88 \mu \mathrm{L}$ of the resulted suspension was transferred to a new $1.5 \mathrm{~mL}$ tube and mixed with $10 \mu \mathrm{L}$ of $10 \times$ KAPA Express Extract Buffer and $2 \mu \mathrm{L}$ of KAPA Express Extract Enzyme (KAPA Biosystems, cat. No. KK7103). After incubation for $22 \mathrm{~min}$ at $75^{\circ} \mathrm{C}$ and $5 \mathrm{~min}$ at $95^{\circ} \mathrm{C}$, the mixture was centrifuged for $1 \mathrm{~min}$ at $16,100 \times \mathrm{g}, 50 \mu \mathrm{L}$ of the supernatant was transferred to a new $1.5-\mathrm{mL}$ tube and resuspended in $200 \mu \mathrm{L}$ of $1 \times$ TE buffer (Serva, cat. No. 39799.01) and frozen at $-20{ }^{\circ} \mathrm{C}$ or used immediately for PCR.

For Nosema detection and determination of Nosema species, two PCR methods were used. Duplex PCR with species-specific primers (321APIS-FOR/REV for detection of $N$. apis and 218MITOC-FOR/REV for detection of $N$. ceranae) designed by Martín-Hernández et al. (2007) and PCR-RFLP with nos-16S-fw/rv primers (Stevanovic et al. 2011) for those samples that failed to produce an amplicon in duplex PCR. Both PCRs were performed the same way as previously described in detail (Stevanovic et al. 2011). Samples that were confirmed to be Nosema negative after amplification with nos-16S-fw/rv primers, were not subjected to digestion with restriction enzymes.

\subsection{Field survey}

$N$. ceranae incidence pattern, symptoms of $N$. ceranae infection and association of $N$. ceranae with colony losses were monitored in the field study. To assess if $N$. ceranae infection display a seasonal pattern, the proportion of $N$. ceranae-positive colonies was determined in each apiary in March, June and October (except October 2012) and obtained $N$. ceranae incidences compared between the three sampling months within each year and between the same sampling months in different years. To reveal if 
there are any symptoms of $N$. ceranae infection, each hive was carefully checked for any obvious outwards signs that resemble those attributed for $N$. apis infection (faecal marks on frames, combs and hive structures; dead and sick crawling bees in the vicinity of the hives) according to Bailey $(1955,1967)$ and the COLOSS workshop (2009). To evaluate if there is association between $N$. ceranae infection and colony losses during the winter and summer seasons, dead colonies were counted in each apiary in mid-March and at the end of November and the proportion of $N$. ceranae-positive colonies were compared between surviving and dead colonies, separately for each season.

\subsection{Statistical analysis}

The Chi-square test was used to compare: (1) the incidence of $N$. ceranae between three sampling months within each year and between the same sampling months in different years; (2) the presence of symptoms between surviving and dead $N$. ceranae positive colonies; and (3) the proportion of $N$. ceranae-positive colonies between surviving and dead colonies, separately for each season (winter and summer).

\section{RESULTS}

\subsection{The incidence of Nosema species and seasonality assessment}

$N$. ceranae was the only Nosema species identified in monitored colonies during the whole study. No $N$. apis or mixed $N$. apis $/ N$. ceranae infections were detected. The results of 5-year survey of $N$. ceranae incidence (Figure 2) revealed the continual high frequency of N. ceranae-positive colonies within each investigated year, ranging from 73 (Jun 2008) to $98 \%$ (March 2010). The highest $N$. ceranae incidence was always recorded in March and ranged from 94 (2008) to $98 \%$ (2010). Lower, but still considerable proportions of $N$. ceranae infected colonies were affirmed in October (76$87 \%$ ) and June (73-91\%). However, statistical analysis using the Chi-square test revealed a significant differences $(P<0.01)$ in $N$. ceranae incidences between three sampling months within each year, except for 2012, the year with no available data for October, and no significant difference in $N$. ceranae incidence between March and June (Table I). When N. ceranae incidences were compared between the same sampling months in different years studied, only March incidences did not significantly differ (Table II). These results were based on PCR analyses of live bees to be comparable between different sampling occasions since faecal samples were not continuously available.

\subsection{Symptoms occurence in N. ceranae-infected colonies}

Clinical symptoms previously described for $N$. apis infection (faecal marks, dead and sick crawling bees) were noticed in this study in most of $N$. ceranae-infected colonies during spring inspection in March. Symptoms of nosemosis were recorded in both surviving (91.6 to $100.0 \%$ ) and dead colonies (77.6 to $100.0 \%$ without significant differences between surviving or dead colonies in 2008 and 2009 (Table III). In 2008 and 2009, the proportions of colonies with symptoms were very

Table I. Differences in Nosema ceranae incidence between three sampling months within each year during the study period (March 2008-June 2012).

\begin{tabular}{lccccc}
\hline Results of $\chi^{2}$ test & \multicolumn{1}{l}{ Year } & & & \\
\cline { 2 - 5 } & 2008 & 2009 & 2010 & 2011 & 2012 \\
\hline$\chi^{2}$ & 21.020 & 30.048 & 51.241 & 14.412 & 3.333 \\
$n$ & 2 & 2 & 2 & 2 & 1 \\
$P$ & $<0.001$ & $<0.001$ & $<0.001$ & 0.001 & 0.068 \\
\hline
\end{tabular}


Table II. Differences in Nosema ceranae incidence between the same sampling months of different years during the study period (March 2008-June 2012).

\begin{tabular}{|c|c|c|c|c|}
\hline \multirow{2}{*}{$\begin{array}{l}\text { Results of } \\
\chi^{2} \text { test }\end{array}$} & \multicolumn{4}{|l|}{ Month } \\
\hline & March & June & October & March-October \\
\hline$\chi^{2}$ & 4.374 & 27.270 & 9.026 & 14.997 \\
\hline$\nu$ & 4 & 4 & 3 & 4 \\
\hline$P$ & 0.358 & $<0.001$ & 0.001 & 0.005 \\
\hline
\end{tabular}

high in both surviving (95.8 and 93.9, respectively) and dead colonies $(100 \%)$ and did not differ significantly $(P=0.350$ and $P=0.128$, respectively) (Table III). However, in 2010, 2011 and 2012, symptoms were significantly more frequently observed among surviving colonies $(P=0.007, P=0.018$ and $P<0.001$, respectively) (Table III). Interestingly, some other subjective observations were noticed in $N$. ceranae-infected colonies during the winter time: the cluster appeared less tight (rather than compact in non-infected colonies) in cold winter days (up to $-5{ }^{\circ} \mathrm{C}$ ); the bees were more anxious than normal on mild winter temperatures $\left(0^{\circ} \mathrm{C}\right.$ or slightly more) manifested through unusually greater number of bees on the hive entrance after sound disturbing (knocking on the outer surfaces of the hive). Among dead colonies during the first spring inspection, we found either plenty of apparently hungry bees (with heads put deep into the comb cells despite sufficient food stores) or typical symptoms of colony collapse disorder (CCD): the complete absence of adult bees in colonies with few or no dead bees in/around colonies; the presence of small amount of capped brood and the presence of food stores (Ellis et al. 2010). CCD-like symptoms were detected only in apiaries situated in agricultural regions (localities No. 1, 2, 3 and 4; Figure 1).

\subsection{The association of $N$. ceranae infection with colony losses during the winter and summer seasons}

Based on colony mortality recorded in March, 24-50\% of monitored colonies died, but there were no significant differences in the proportion of $N$. ceranae infected colonies between surviving and dead colonies during winter season in the period 2008-2011 (Table IV). Only in 2012, N. ceranae was significantly more $(P=0.012)$ present among

Table III. Symptoms occurence at the end of winter season in surviving and dead Nosema ceranae-infected colonies over 5 years of study (2008-2012).

\begin{tabular}{|c|c|c|c|c|c|c|c|c|c|c|c|c|}
\hline \multirow[t]{3}{*}{ Year } & \multirow{3}{*}{$\begin{array}{l}\text { Total No. of } \\
N . \text { ceranae- } \\
\text { positive } \\
\text { colonies } \\
\text { in March }\end{array}$} & \multicolumn{4}{|c|}{ Surviving colonies } & \multicolumn{4}{|c|}{ Dead colonies } & \multirow{3}{*}{$\begin{array}{l}\% \\
\text { colony } \\
\text { losses }\end{array}$} & \multicolumn{2}{|c|}{ Results of $\chi^{2}$ test } \\
\hline & & \multicolumn{2}{|c|}{$\begin{array}{l}\text { With } \\
\text { symptoms }\end{array}$} & \multicolumn{2}{|c|}{$\begin{array}{l}\text { Without } \\
\text { symptoms }\end{array}$} & \multicolumn{2}{|c|}{$\begin{array}{l}\text { With } \\
\text { symptoms }\end{array}$} & \multicolumn{2}{|c|}{$\begin{array}{l}\text { Without } \\
\text { symptoms }\end{array}$} & & \multirow[t]{2}{*}{$\chi^{2}$} & \multirow[t]{2}{*}{$P(\nu=1)$} \\
\hline & & No & $\%$ & No & $\%$ & No & $\%$ & No & $\%$ & & & \\
\hline 2008 & 188 & 136 & 95.8 & 6 & 4.3 & 46 & 100.0 & 0 & 0.0 & 24.5 & 0.87 & 0.350 \\
\hline 2009 & 190 & 124 & 93.9 & 8 & 6.1 & 58 & 100.0 & 0 & 0.0 & 30.5 & 2.32 & 0.128 \\
\hline 2010 & 196 & 117 & 92.9 & 9 & 7.1 & 55 & 78.6 & 15 & 21.4 & 35.7 & 7.27 & 0.007 \\
\hline 2011 & 192 & 131 & 91.6 & 12 & 8.4 & 38 & 77.6 & 11 & 22.4 & 25.5 & 5.57 & 0.018 \\
\hline 2012 & 200 & 100 & 100.0 & 0 & 0.0 & 78 & 78.0 & 22 & 22.0 & 50.0 & 124.61 & $<0.001$ \\
\hline
\end{tabular}


Table IV. The association of Nosema ceranae infection with colony losses during the winter season based on the proportions of $N$. ceranae-positive colonies among surviving and dead colonies (in period 2008-2012).

\begin{tabular}{|c|c|c|c|c|c|c|c|c|c|c|}
\hline \multirow[t]{2}{*}{$\begin{array}{l}\text { Winter } \\
\text { season }\end{array}$} & \multirow{2}{*}{$\begin{array}{l}\text { Total No. } \\
\text { of colonies } \\
\text { analysed in } \\
\text { March }\end{array}$} & \multicolumn{3}{|c|}{ No. of surviving colonies } & \multicolumn{3}{|c|}{ No. of dead colonies } & \multirow{2}{*}{$\begin{array}{l}\% \\
\text { colony } \\
\text { losses }\end{array}$} & \multicolumn{2}{|c|}{$\begin{array}{l}\text { Results of } \\
\chi^{2} \text { test }\end{array}$} \\
\hline & & Total & $\begin{array}{l}N \text {. ceranae } \\
\text { positive }\end{array}$ & $\begin{array}{l}N . \text { ceranae } \\
\text { negative }\end{array}$ & Total & $\begin{array}{l}N . \text { ceranae } \\
\text { positive }\end{array}$ & $\begin{array}{l}N \text {. ceranae } \\
\text { negative }\end{array}$ & & $\chi^{2}$ & $P(\nu=1)$ \\
\hline 2008 & 200 & 152 & 142 & 10 & 48 & 46 & 2 & 24.0 & 0.07 & 0.791 \\
\hline 2009 & 200 & 142 & 132 & 10 & 58 & 58 & 0 & 29.0 & 2.94 & 0.086 \\
\hline 2010 & 200 & 130 & 126 & 4 & 70 & 70 & 0 & 35.0 & 0.91 & 0.341 \\
\hline 2011 & 200 & 149 & 143 & 6 & 51 & 49 & 2 & 25.5 & 0.15 & 0.703 \\
\hline 2012 & 200 & 100 & 92 & 8 & 100 & 100 & 0 & 50.0 & 6.38 & 0.012 \\
\hline
\end{tabular}

dead colonies (Table IV). In the same winter (2012), all dead colonies were infected with $N$. ceranae (Table IV), and the highest proportion of colony loss was recorded (50\%) compared with other years of this study (Tables IV and V). Based on the results presented in Table $\mathrm{V}$, winter colony losses could not be related to altitudes of localities. Nevertheless, it should be

Table V. Winter colony losses (number per localities) during the study period (2008-2012).

\begin{tabular}{|c|c|c|c|c|c|c|}
\hline Locality ${ }^{\mathrm{a}}$ No. & Altitude (m) & March 2008 & March 2009 & March 2010 & March 2011 & March 2012 \\
\hline 1 & 47 & 4 & 5 & 6 & 5 & 8 \\
\hline 2 & 87 & 2 & 3 & 4 & 2 & 7 \\
\hline 3 & 84 & 3 & 5 & 6 & 4 & 6 \\
\hline 4 & 183 & 4 & 4 & 3 & 5 & 7 \\
\hline 5 & 99 & 2 & 2 & 5 & 4 & 7 \\
\hline 6 & 245 & 1 & 2 & 3 & 3 & 8 \\
\hline 7 & 100 & 3 & 5 & 6 & 4 & 6 \\
\hline 8 & 100 & 2 & 3 & 2 & 1 & 0 \\
\hline 9 & 200 & 3 & 5 & 6 & 5 & 10 \\
\hline 10 & 1,113 & 4 & 4 & 6 & 5 & 9 \\
\hline 11 & 1,100 & 3 & 2 & 4 & 3 & 8 \\
\hline 12 & 188 & 3 & 5 & 6 & 3 & 7 \\
\hline 13 & 500 & 2 & 2 & 2 & 1 & 3 \\
\hline 14 & 777 & 0 & 1 & 0 & 0 & 0 \\
\hline 15 & 600 & 0 & 2 & 0 & 1 & 0 \\
\hline 16 & 435 & 2 & 2 & 0 & 1 & 0 \\
\hline 17 & 330 & 2 & 1 & 3 & 1 & 4 \\
\hline 18 & 250 & 3 & 2 & 2 & 1 & 2 \\
\hline 19 & 464 & 3 & 2 & 2 & 1 & 4 \\
\hline 20 & 250 & 2 & 1 & 4 & 1 & 4 \\
\hline $\begin{array}{l}\text { Total No. of } \\
\text { dead colonies } \\
\text { during winter }\end{array}$ & & 48 & 58 & 70 & 51 & 100 \\
\hline
\end{tabular}

\footnotetext{
${ }^{\mathrm{a}}$ The distribution and the names of localities are presented in Figure 1
} 
noted that the best survival rate of the colonies was found at localities No. 14, 15 and 16 on altitudes 777, 600 and $435 \mathrm{~m}$, respectively, and the greatest loss of colonies was recorded in locality No. 9 (on altitude $200 \mathrm{~m}$ ) where no colony survived the winter 2012 (Figure 1, Table V). During the summer, the percentage of lost colonies (1.5-4\%) was much lower than in the winter season and no significant differences in the proportion of $N$. ceranae-infected colonies were affirmed between colonies that survived and those that died in 2008, 2009 and 2011 (Table VI). In 2010, significantly higher $(P=0.029)$ number of $N$. ceranae-positive colonies survived (Table VI).

Microscopic examination of feacal samples showed $100 \%$ of the samples to be infected. However, when live bees were analysed, PCR revealed Nosema infection in $5 \%$ more samples compared with microscopy. Faecal samples gave consistent results in Nosema detection, being $100 \%$ Nosema positive, either by microscopy or PCR. Nosema species was successfully determined in all faecal samples. Dead bees appeared non-adequate for Nosema detection because their analyses (either by microscopy or by PCR) did not reveal $N$. ceranae infection in $12 \%$ of colonies confirmed as Nosema positive by analyses of live bees and faeces sampled at the same time from the same colonies.

\section{DISCUSSION}

The detection of only $N$. ceranae species in this study is in agreement with previously reported dominance of this microsporodian pathogen in honey bees from Serbia (Stevanovic et al. 2011). No samples positive to $N$. apis were found in this study using conventional PCR methods (duplex PCR and PCR-RFLP), that are commonly used for molecular identification of Nosema species (Martín-Hernández et al. 2007; 2009; 2011b; Higes et al. 2010b; Stevanovic et al. 2011; Gisder et al. 2010; Hedtke et al. 2011). Duplex real-time PCR assay was reported to be more sensitive than duplex conventional PCR in identification of $N$. apis, although it showed greater efficacy only in two co-infected samples (Burgher-MacLellan et al. 2010).

Investigation of $N$. ceranae seasonality in adult bee samples revealed significant differences $(P<$ $0.01)$ in the proportion of $N$. ceranae-infected colonies between the three sampling months (March, June and October) within each year in period 2008-2011. These results suggest a seasonal pattern in $N$. ceranae incidence during the four specified years. However, we found no significant differences between March and June within 2012. The significant increase in $N$. ceranae incidence in June 2012 compared with June incidences recorded in previous years (Table II) probably contributed to the apparent loss of seasonality. Nevertheless, any conclusion regarding seasonality in $N$. ceranae incidence remains in question as no infection threshold or criteria for seasonal prevalence determination have ever been defined. Accordingly, statistically significant differences affirmed between monthly frequencies of $N$. ceranae positive samples may not obligatory reflect the seasonality in $N$. ceranae

Table VI. The association of Nosema ceranae infection with colony losses during the summer season based on the proportions of $N$. ceranae-positive colonies among colonies that survived and that died (2008-2012).

\begin{tabular}{|c|c|c|c|c|c|c|c|c|c|c|}
\hline \multirow[t]{2}{*}{$\begin{array}{l}\text { Summer } \\
\text { season }\end{array}$} & \multirow{2}{*}{$\begin{array}{l}\text { Total No. } \\
\text { of colonies } \\
\text { analysed in } \\
\text { November }\end{array}$} & \multicolumn{3}{|c|}{ No. of survived colonies } & \multicolumn{3}{|c|}{ No. of dead colonies } & \multirow{2}{*}{$\begin{array}{l}\% \\
\text { colony } \\
\text { losses }\end{array}$} & \multicolumn{2}{|c|}{$\begin{array}{l}\text { Results } \\
\text { of } \chi^{2} \text { test }\end{array}$} \\
\hline & & Total & $\begin{array}{l}N . \text { ceranae } \\
\text { positive }\end{array}$ & $\begin{array}{l}N . \text { ceranae } \\
\text { negative }\end{array}$ & Total & $\begin{array}{l}N \text {. ceranae } \\
\text { positive }\end{array}$ & $\begin{array}{l}N . \text { ceranae } \\
\text { negative }\end{array}$ & & $\chi^{2}$ & $P(\nu=1)$ \\
\hline 2008 & 200 & 196 & 162 & 34 & 4 & 4 & 0 & 2.0 & 0.06 & 0.809 \\
\hline 2009 & 200 & 195 & 156 & 39 & 5 & 2 & 3 & 2.5 & 2.60 & 0.107 \\
\hline 2010 & 200 & 192 & 149 & 43 & 8 & 3 & 5 & 4.0 & 4.75 & 0.029 \\
\hline 2011 & 200 & 197 & 171 & 26 & 3 & 3 & 0 & 1.5 & 0.04 & 0.849 \\
\hline
\end{tabular}


incidence. In our study, the proportion of $N$. ceranae positive live adult bee samples were never under $73 \%$, and exceeded $80 \%$ in nine of 14 sampling occasions (Figure 2). Such high $N$. ceranae incidences are quite similar to those recorded in Spain in 2005 (Martín-Hernández et al. 2007), but they observed total lack of seasonality in that year because monthly values did not differ significantly. In contrast, Gisder et al. (2010) reported seasonality in $N$. ceranae infected colonies in Germany in period 20072009 but without any statistical evaluation of differences between spring and autumn proportions of Nosema-infected colonies. Besides, they found much lower proportions of $N$. ceranaepositive colonies (ranging from 1.3 to $14.9 \%$ ) than we recorded in this study (73-98\%). Such differences in $N$. ceranae prevalence between Germany and Serbia may be due to existence of both Nosema species in Germany, but also due to the differences in sample size and sensitivity of method for Nosema detection. We used 60 bees per sample and applied both microscopy and PCR for Nosema detection, whereas Gisder et al. (2010) used only microscopy to detect Nosema spores and only 20 bees per sample. Such low sample sizes are unreliable for Nosema diagnosis (Fries et al. 1984), particularly in spring months when more newly born uninfected bees are present (Botías et al. 2012). In addition, obvious seasonal patterns of $N$. ceranae incidence have been reported from the USA (Runckel et al. 2011; Traver et al. 2012).

To conclude, based on statistical analysis, $N$. ceranae exerted a seasonal pattern in Serbia in the 4-year period (2008-2011). Such findings are not in agreement with conclusions of MartínHernández et al. (2007) and Higes et al. (2010a) who attribute seasonal pattern only for $N$. apis and not for N. ceranae based on their findings in Spain.

No statistically significant $N$. ceranae seasonality was identified in 2012; however, a seasonal effect may be present when October samples are processed. Here, it is also important to mention that in tropical or subtropical climates, where bees were able to fly all year around, no seasonal pattern in N. apis infections was found (Fries and Raina 2003). Thus, seasonal pattern of prevalence may be dependent on climatic conditions (Fries 2010) not on Nosema species. After all, for reliable seasonality estimation, standards for Nosema monitoring and thresholds in incidence rating are needed and should be defined.

$N$. ceranae incidences measured in June and October were statistically different among years of this study, possibly as a reflection of climatic changes in Serbia during the past decade. Based on the data reported by Republic Hydrometeorological Sevice of Serbia (RHMZ) in the previous 5 years, the average temperatures continually increased, being $2{ }^{\circ} \mathrm{C}$ (2008-2010) and even $3{ }^{\circ} \mathrm{C}$ higher (in the first half of 2012) in comparison with the previous temperature averages. Summers were extremely hot and dry during the whole study period, and especially in 2012, when number of tropical days doubled compared with the previous years. Maximal temperatures exceeded $+38{ }^{\circ} \mathrm{C}$ during the summer 2009 and 2012. On the other hand, wide temperature amplitudes were recorded in February (from -27 to $+10{ }^{\circ} \mathrm{C}$ ). Such temperature variations obviously did not decrease $N$. ceranae prevalence as it maintained and even increased the incidence in Serbia over the last 5 years.

In this study, the symptoms traditionally attributed to $N$. apis infection (faecal marks, dead and sick crawling bees) were observed in the majority of $N$. ceranae-infected colonies. These findings are not in agreement with finding of Higes et al. (2008, 2009) who reported the absence of clinical symptoms in colonies infected solely with $N$. ceranae in Spain (nosemosis type $\mathrm{C}$ ). The fact that we found the symptoms among both surviving and dead colonies, being even more frequent among surviving colonies in the last 3 years (2010-2012) indicates that these symptoms could not serve as predictive markers for colony losses. The observations of loose cluster and anxiety in bees during winter with apparently hungry bees on the first spring inspection could be the result of increased energetic stress attributed to $N$. ceranae-infected bees (Mayack and Naug 2009) as the starvation and lack of thermoregulatory capacity are related 
with increased energetic stress (Martín-Hernández et al. 2011b).

No clear association of $N$. ceranae infection with colony losses were affirmed in this study, neither during the winter nor during the summer season, since in four out of five seasons no significant differences in $N$. ceranae incidence were affirmed between surviving and colonies that died. These results are consistent with previous reports of Cox-Foster et al. (2007); vanEngelsdorp et al. (2009); Genersch et al. (2010); Gisder et al. (2010); Vejsnæs et al. (2010); Stevanovic et al. (2011); Dainat et al. (2012) who also revealed no relation between colony mortality and $N$. ceranae prevalence.

The highest proportion of colony loss (50\%) recorded in March 2012 is probably the consequence of extreme temperature variations during the previous winter. The average monthly temperature in February 2012 was $6.6^{\circ} \mathrm{C}$ lower than in previous years, and extremely low temperatures of $-27{ }^{\circ} \mathrm{C}$ were often recorded (RHMZ). Besides, December 2011 and January 2012 were mild, with average temperatures higher than previous years (RHMZ), so the bees were active longer than usually. As the honey bees did not enter into winter hibernation beforehand, the brood was present till December 1st probably with a higher consumption of food as a result. Consequently, the bees may have been exhausted and did not survive extremely cold temperatures in February 2012. As $N$. ceranae was found in all colonies that died in winter 2012, the influence of this parasite should not be neglected, knowing its role on honey bee immune suppression (Antúnez et al. 2009; Chaimanee et al. 2012) and energetic stress (Mayack and Naug 2009).

Best survival rates of honey bee colonies recorded at three localities (No. 14, 15 and 16, on altitudes 777, 600 and $435 \mathrm{~m}$, respectively) are probably the results of their better adaptation to low temperatures. Previously evidenced genetic and behavioural differences among different ecotypes of Serbian honey bees (Stanimirovic et al. 2002, 2005a, b; Stevanovic et al. 2010; Muñoz et al. 2012) support the idea that bees from Southern and Eastern regions of Serbia (localities No. 14, 15 and 16) may have better adaptation abilities.

Nosema spores could be detected from bee and faecal samples under the microscope (OIE 2008; Higes et al. 2010a). In our study, microscopic examination gave $100 \%$ reliable results (compared with PCR) only when faecal samples were analysed, while analyses of live bees gave congruent result in $95 \%$ of cases when compared with PCR. Faecal samples in this study are used for the first time for both Nosema detection and species identification. This type of sample appeared most reliable for Nosema detection, either by microscopy or PCR and also adequate for identification of Nosema species. Accordingly, when available, faeces could be a sample of choice for Nosema diagnostic purposes. Besides, in dead colonies, faeces is the only reliable sample for Nosema diagnosis, as dead bees often gave falsenegative results $(12 \%$ in our study and $73.3 \%$ in the study of Tlak Gajger et al. 2010). When live bees are used as sample for Nosema diagnosis, PCR proved to be more reliable than microscopy. In fact, PCR in this study revealed Nosema infection in $5 \%$ of live bee samples that appeared Nosema-free under the microscope. That could be explained by several factors. Simple, a non-quantitative microscopic method for detecting Nosema infection used in this study (according to the guidelines of OIE 2008) does not imply purification of suspensions (by filtering and/or centrifugation), thus enabling to overlook Nosema spores due to coarse parts originating from 60 bee abdomens macerated in very small amount of water. In addition, all samples in our study were $N$. ceranae, previously evidenced to have higher proportion of immature stages (70 \%) than of mature stages (MartínHernández et al. 2009), that could make it possible to overlook $N$. ceranae infection by light microscopy in bee samples, especially in early stages of infection. The proportion of false-negative live bee samples were much 
greater in the study of Traver and Fell (2011) who microscopically overlooked Nosema spores in $51.1 \%$ of colonies that subsequently, using realtime PCR, were revealed to be $N$. cearane infected. The facts that PCR detection methods have greater sensitivity (Bourgeois et al. 2010; Hamiduzzaman et al. 2010; Traver and Fell 2011) and the ability to detect immature stages of microsporidia and $N$. ceranae infection in other tissues as hypopharyngeal glands, salivary glands, malpighian tubules, fat bodies and brain (Chen et al. 2009; Gisder et al. 2010) are good reasons to explain why in some cases Nosema infection in live bee samples is not detected by microscopy but positive using PCR. However, it should be noted that sampling of live bees for Nosema diagnosis is accompanied by several issues that notably affect the diagnosis (Botías et al. 2012). These problems could be overcome with sampling and analysing feces when available in accordance with the protocol we presented in this study.

\section{CONCLUSIONS}

$N$. ceranae infection in Serbian honey bee colonies do not resemble the characteristics described for nosemosis type $\mathrm{C}$, previoulsy attributed for $N$. ceranae-infected bees in Spain (Martín-Hernández et al. 2007; Higes et al. 2008, 2009), because we affirmed seasonality in $N$. ceranae incidence, symptoms traditionally attributed to $N$. apis infection (faecal marks, dead and sick crawling bees) in majority of $N$. ceranaeinfected colonies, and no association between $N$. ceranae infection and colony loss. The fact that we found the symptoms among both surviving colonies and colonies that died, being even more frequent among surviving colonies in the last three years of the study (2010-2012) indicates that these symptoms could not serve as predictive markers for colony losses. Faeces could be recommended as a sample of choice for Nosema diagnostic purposes always when available, as in this study it appeared to be the most reliable method for $N$. ceranae detection, either by microscopy or by PCR.

\section{ACKNOWLEDGMENTS}

This study was supported by the Ministry of Education, Science and Technological Development of the Republic of Serbia (grant No. III 46002).

Caractéristiques de l'infection par Nosema ceranae dans les colonies d'abeilles de Serbie

Nosema ceranae / Apis mellifera / nosémose de type $\mathrm{C}$ / fèces / maladie de l'abeille

Merkmale der Infektionen mit Nosema ceranae in Bienenvölkern in Serbien

Nosema ceranae / Apis mellifera / Nosemose Typ C / Fäzes

\section{REFERENCES}

Alaux, C., Brunet, J.L., Dussaubat, C., Mondet, F., Tchamitchan, S., Cousin, M., Brillard, J., Baldy, A., Belzunces, L.P., Le Conte, Y. (2010) Interactions between Nosema microspores and a neonicotinoid weaken honeybees (Apis mellifera). Environ. Microbiol. 12, 774-782

Antúnez, K., Martín-Hernández, R., Prieto, L., Meana, A., Zunino, P., Higes, M. (2009) Immune suppression in the honey bee (Apis mellifera) following infection by Nosema ceranae (Microsporidia). Environ. Microbiol. 11, 2284-2290

Bacandritsos, N., Granato, A., Budge, G., Papanastasiou, I., Roinioti, E., Caldon, M., Falcaro, C., Gallina, A., Mutinelli, F. (2010) Sudden deaths and colony population decline in Greek honey bee colonies. J. Invertebr. Pathol. 105, 335-340

Bailey, L. (1955) The epidemiology and control of Nosema disease of the honey bee. Ann. Appl. Biol. 43, 379-389

Bailey, L. (1967) Nosema apis and dysentery of the honey bee. J. Apic. Res. 6, 121-125

Botías, C., Martín-Hernández, R., Garrido-Bailón, E., González-Porto, A., Martínez-Salvador, A., De La Rúa, P., Meana, A., Higes, M. (2012) Critical aspects of the Nosema spp. diagnostic sampling in honey bee (Apis mellifera L.) colonies. Parasitol. Res. 110, 2557-2561

Bourgeois, A.L., Rinderer, E.T., Beaman, D.L., Danka, G.R. (2010) Genetic detection and quantification of Nosema apis and N. ceranae in the honey bee. J. Invertebr. Pathol. 103, 53-58

Bromenshenk, J.J., Henderson, C.B., Wick, C.H., Stanford, M.F., Zulich, A.W., et al. (2010) Iridovirus and microsporidian linked to honey bee colony decline. PLoS One 5, e13181 
Burgher-MacLellan, K.L., Williams, G.R., Shutler, D., MacKenzie, K., Rogers, R.E.L. (2010) Optimization of duplex real-time PCR with melting-curve analysis for detecting the microsporidian parasites Nosema apis and Nosema ceranae in Apis mellifera. Can. Entomol. 142, 271-283

Chaimanee, V., Chantawannakul, P., Chen, Y., Evans, J.D., Pettis, J.S. (2012) Differential expression of immune genes of adult honey bee (Apis mellifera) after inoculated by Nosema ceranae. J. Insect Physiol. 58, 1090-1095

Chauzat, M.P., Higes, M., Martín-Hernández, R., Meana, A., Cougoule, N., Faucon, J.P. (2007) Presence of Nosema ceranae in French honeybee colonies. J. Apic. Res. 46, 127-128

Chen, Y., Evans, J.D., Smith, I.B., Pettis, J.S. (2008) Nosema ceranae is a long-present and widespread microsporidean infection of the European honey bee (Apis mellifera) in the United States. J. Invertebr. Pathol. 97, 186-188

Chen, Y.P., Evans, J.D., Murphy, C., Gutell, R., Zuker, M., Gundensen-Rindal, D., Pettis, J.S. (2009) Morphological, molecular, and phylogenetic characterization of Nosema ceranae, a microsporidian parasite isolated from the European honey bee, Apis mellifera. J. Eukaryot. Microbiol. 56, 142-147

COLOSS workshop (2009). Conclusions, Proc. Workshop "Nosema disease: lack of knowledge and work standardization" (COST Action FA0803) Guadalajara. http://www.coloss.org/news/nosema-workshopproceedings-online. Accessed 20 Nov 2009

Cox-Foster, D.L., Conlan, S., Holmes, E.C., Palacios, G., Evans, J.D., et al. (2007) A metagenomic survey of microbes in honey bee colony collapse disorder. Science 318, 283-287

Dainat, B., Evans, J.D., Chen, Y.P., Gauthier, L., Neumann, P. (2012) Predictive markers of honey bee colony collapse. PLoS One 7, e32151

Ellis, J.D., Evans, J.D., Pettis, J. (2010) Colony losses, managed colony population decline, and colony collapse disorder in the United States. J. Apic. Res. 49, 134-136

Fernández, J.M., Puerta, F., Cousinou, M., Dios-Palomares, R., Campano, F., Redondo, L. (2012) Asymptomatic presence of Nosema spp. in Spanish commercial apiaries. J. Invertebr. Pathol. 111, 106-110

Forsgren, E., Fries, I. (2010) Comparative virulence of Nosema ceranae and Nosema apis in individual European honey bees. Vet. Parasitol. 170, 212-217

Fries, I. (2010) Nosema ceranae in European honey bees (Apis mellifera). J. Invertebr. Pathol. 103, S73-S79

Fries, I., Forsgren, E. (2008) Undersökning av spridningen av Nosema ceranae i Sverige. Investigation of the distribution of Nosema ceranae in Sweden Bitidningen 107, januari/februari, pp. 26-27 (in Swedish)

Fries, I., Raina, S. (2003) American foulbrood (Paenibacillus larvae larvae) and African honey bees (Apis mellifera scutellata). J. Econ. Entomol. 96, 1641-1646

Fries, I., Ekbohm, G., Villumstad, E. (1984) Nosema apis, sampling techniques and honey yield. J. Apic. Res. 23, 102-105

Fries, I., Feng, F., da Silva, A., Slemenda, S.B., Pieniazek, J. (1996) Nosema ceranae n. sp. (Microspora, Nosematidae), morphological and molecular characterization of a microsporidian parasite of the Asian honey bee Apis cerana (Hymenoptera, Apidae). Eur. J. Protistol. 32, 356-365

Fries, I., Martín, R., Meana, A., García-Palencia, P., Higes, M. (2006) Natural infections of Nosema ceranae in European honey bees. J. Apic. Res. 45, 230-233

Genersch, E., von der Ohe, W., Kaatz, H., Schroeder, A., Otten, C., et al. (2010) The German bee monitoring project: a long term study to understand periodically high winter losses of honey bee colonies. Apidologie 41, 332-352

Giersch, T., Berg, T., Galea, F., Hornitzky, M. (2009) Nosema ceranae infects honey bees (Apis mellifera) and contaminates honey in Australia. Apidologie 40, $117-123$

Gisder, S., Hedtke, K., Möckel, N., Frielitz, M.-C., Linde, A., Genersch, E. (2010) Five-year cohort study of Nosema spp. in Germany: does climate shape virulence and assertiveness of Nosema ceranae? Appl. Environ. Microb. 76, 3032-3038

Hamiduzzaman, M.M., Guzman-Novoa, E., Goodwin, P.H. (2010) A multiplex PCR assay to diagnose and quantify Nosema infections in honey bees (Apis mellifera). J. Invertebr. Pathol. 105, 151-155

Hedtke, K., Jensen, P.M., Jensen, A.B., Genersch, E. (2011) Evidence for emerging parasites and pathogens influencing outbreaks of stress-related diseases like chalkbrood. J. Invertebr. Pathol. 108, 167-173

Higes, M., Martín, R., Meana, A. (2006) Nosema ceranae, a new microsporidian parasite in honeybees in Europe. J. Invertebr. Pathol. 92, 93-95

Higes, M., Martín-Hernández, R., Botías, C., Garrido Bailón, E., González-Porto, A.V., et al. (2008) How natural infection by Nosema ceranae causes honeybee colony collapse. Environ. Microbiol. 10, 2659-2669

Higes, M., Martín-Hernández, R., Garrido-Bailón, E., González-Porto, A.V., García-Palencia, P., Meana, A., del Nozal, M.J., Mayo, R., Bernal, J.L. (2009) Honeybee colony collapse due to Nosema ceranae in professional apiaries. Environ. Microbiol. Rep. 1, 110-113

Higes, M., Martín-Hernández, R., Meana, A. (2010a) Nosema ceranae in Europe: an emergent type C nosemosis. Apidologie 41, 375-392

Higes, M., Martín-Hernández, R., Martínez-Salvador, A., Garrido-Bailón, E., González-Porto, A.V., Meana, A., Bernal, J.L., del Nozal, M.J., Bernal, J. (2010b) A preliminary study of the epidemiological factors related to honey bee colony loss in Spain. Environ. Microbiol. Rep. 2, 243-250 
Huang, W.F., Jiang, J.H., Chen, Y.W., Wang, C.H. (2007) A Nosema ceranae isolate from the honeybee Apis mellifera. Apidologie 38, 30-37

Invernizzi, C., Abud, C., Tomasco, I.H., Harriet, J., Ramallo, G., Campá, J., Katz, H., Gardiol, G., Mendoza, Y. (2009) Presence of Nosema ceranae in honeybees (Apis mellifera) in Uruguay. J. Invertebr. Pathol. 101, 150-153

Klee, J., Besana, A.M., Genersch, E., Gisder, S., Nanetti, A., et al. (2007) Widespread dispersal of the microsporidian Nosema ceranae, an emergent pathogen of the western honey bee, Apis mellifera. J. Invertebr. Pathol. 96, 1-10

Martín-Hernández, R., Meana, A., Prieto, L., Salvador, A.M., Garrido-Bailón, E., Higes, M. (2007) Outcome of colonization of Apis mellifera by Nosema ceranae. Appl. Environ. Microb. 73, 6331-6338

Martín-Hernández, R., Meana, A., García-Palencia, P., Marín, P., Botías, C., Garrido-Bailón, E., Barrios, L., Higes, M. (2009) Effect of temperature on the biotic potential of honeybee microsporidia. Appl. Environ. Microb. 75, 2554-2557

Martín-Hernández, R., Botías, C., Garrido Bailón, E., Martínez-Salvador, A., Prieto, L., Meana, A., Higes, M. (2011a) Microsporidia infecting Apis mellifera: coexistence or competition. Is Nosema ceranae replacing Nosema apis? Environ. Microbiol. 14, 2127-2138

Martín-Hernández, R., Botías, C., Barrios, L., MartínezSalvador, A., Meana, A., Mayack, C., Higes, M. (2011b) Comparison of the energetic stress associated with experimental Nosema ceranae and Nosema apis infection of honeybees (Apis mellifera). Parasitol. Res. 109, 605-612

Mayack, C., Naug, D. (2009) Energetic stress in the honeybee Apis mellifera from Nosema ceranae infection. J. Invertebr. Pathol. 100, 185-188

Meana, A., Martín-Hernández, R., Higes, M. (2010) The reliability of spore counts to diagnose Nosema ceranae infections in honey bees. J. Apic. Res. 49, 212-214

Muñoz, I., Stevanovic, J., Stanimirovic, Z., De la Rúa, P. (2012) Genetic variation of Apis mellifera from Serbia inferred from mitochondrial analysis. J. Apic. Sci. 56, 59-69

Nabian, S., Ahmadi, K., Nazem Shirazi, M.H., Gerami Sadeghian, A. (2011) First detection of Nosema ceranae, a microsporidian protozoa of European honeybees (Apis mellifera) in Iran. Iran. J. Parasitol. 6, 89-95

OIE (2008) Office International des Epizooties, Manual of Diagnostic Tests and Vaccines for Terrestrial Animals, Chap. 2.2.4., Nosemosis of Honey Bees. http://www.oie.int/fileadmin/Home/eng/ Health_standards/tahm/2.02.04_NOSEMOSIS.pdf

Paxton, R.J. (2010) Does infection by Nosema ceranae cause Colony Collapse Disorder in honey bees (Apis mellifera)? J. Apic. Res. 49, 80-84
Paxton, R.J., Klee, J., Korpela, S., Fries, I. (2007) Nosema ceranae has infected Apis mellifera in Europe since at least 1998 and may be more virulent than Nosema apis. Apidologie 38, 558565

RHMZ, Republic Hydrometeorological Sevice of Serbia. http://www.hidmet.gov.rs/index_eng.php

Runckel, C., Flenniken, M.L., Engel, J.C., Ruby, J.G., Ganem, D., Andino, R., DeRisi, J.L. (2011) Temporal analysis of the honey bee microbiome reveals four novel viruses and seasonal prevalence of known viruses, Nosema, and Crithidia. PLoS One 6, e 20656

Stanimirovic, Z., Pejovic, D., Stevanovic, J., Vucinic, M., Mirilovic, M. (2002) Investigations of hygienic behaviour and disease resistance in organic beekeeping of two honeybee ecogeographic varieties from Serbia. Acta Vet.-Beograd 52, 169180

Stanimirovic, Z., Stevanovic, J., Andjelkovic, M. (2005a) Chromosomal diversity in Apis mellifera carnica from Serbia. Apidologie 36, 31-42

Stanimirovic, Z., Stevanovic, J., Cirkovic, D. (2005b) Behavioural defenses of the honey bee ecotype from Sjenica-Pester against Varroa destructor. Acta Vet.-Beograd 55, 69-82

Stevanovic, J., Stanimirovic, Z., Radakovic, M., Kovacevic, R.S. (2010) Biogeographic study of the honey bee (Apis mellifera L.) from Serbia, Bosnia and Herzegovina and Republic of Macedonia based on mitochondrial DNA analyses. Russ. J. Genet. 46, 603-609

Stevanovic, J., Stanimirovic, Z., Genersch, E., Kovacevic, R.S., Ljubenkovic, J., Radakovic, M., Aleksic, N. (2011) Dominance of Nosema ceranae in honey bees in the Balkan countries in the absence of symptoms of colony collapse disorder. Apidologie 41, 49-58

Tapaszti, Z., Forgách, P., Kovágó, C., Békési, L., Bakonyi, T., Rusvai, M. (2009) First detection and dominance of Nosema ceranae in Hungarian honeybee colonies. Acta Vet. Hung. 57, 383-388

Tlak Gajger, I.T., Vugrek, O., Grilec, D., Petrinec, Z. (2010) Prevalence and distribution of Nosema ceranae in Croatian honeybee colonies. Vet. Med.Czech 55, 457-462

Traver, B.E., Fell, R.D. (2011) Prevalence and infection intensity of Nosema in honey bee (Apis mellifera L.) colonies in Virginia. J. Invertebr. Pathol. 107, 43-49

Traver, B.E., Williams, M.R., Fell, R.D. (2012) Comparison of within hive sampling and seasonal activity of Nosema ceranae in honey bee colonies. J. Invertebr. Pathol. 109, 187-193

vanEngelsdorp, D., Evans, J.D., Saegerman, C., Mullin, C., Haubruge, E., et al. (2009) Colony collapse disorder: a descriptive study. PLoS One 4, e6481

Vejsnæs, F., Nielsen, S.L., Kryger, P. (2010) Factors involved in the recent increase in colony losses in Denmark. J. Apic. Res. 49, 109-110 
Vidau, C., Diogon, M., Aufauvre, J., Fontbonne, R., Viguès, B., et al. (2011) Exposure to sublethal doses of fipronil and thiacloprid highly increases mortality of honeybees previously infected by Nosema ceranae. PLoS One 6, e21550

Williams, G.R., Shafer, A.B.A., Rogers, R.E.L., Shutler, D., Stewart, D.T. (2008) First detection of Nosema ceranae, a microsporidean parasite of European honey bees (Apis mellifera), in Canada and central USA. J. Invertebr. Pathol. 97, 189192

Zander, E. (1909) Tierische Parasiten als Krankheitserreger bei der Biene. Münchener Bienenzeitung 31, 196204 